\title{
Ética e Economia
}





\title{
Renda básica: renda mínima garantida para o século XXI?*
}

\author{
PHILIPPE VAN PARIJS
}

$D$

EEM A TODOS os cidadãos uma renda modesta, porém incondicional, e deixem-nos completá-la à vontade com renda proveniente de outras fontes. Esta idéia extremamente simples tem uma origem surpreendentemente variada. Ao longo dos dois últimos séculos, ela tem sido concebida de maneira independente sob uma variedade de nomes - "dividendo territorial" e "bônus estatal", por exemplo, "demogrant" e "salário do cidadão", "benefício universal" e "renda básica" -, na maioria dos casos sem muito sucesso. Porém, nas duas últimas décadas, ela aos poucos se tornou o assunto de uma discussão pública nunca vista e que se expande rapidamente. Alguns a consideram um remédio crucial para muitos males sociais, inclusive para o desemprego e a pobreza. Outros a denunciam como uma proposta louca, economicamente falha, eticamente censurável, a ser esquecida o mais breve possível e jogada de uma vez por todas na lata de lixo da história das idéias.

Para lançar luz sobre este debate, começo dizendo mais sobre o que é e o que não é renda básica e sobre aquilo que a distingue de sistemas de renda garantida existentes. Neste contexto será mais fácil entender por que a renda básica tem atraído tanta atenção ultimamente, por que se pode esperar que haja uma forte resistência [contra ela] e como essa resistência será finalmente superada. $\mathrm{O}$ autor está convencido de que a renda básica não será esquecida, de que ela não deve ser descartada e de que ela é uma daquelas poucas idéias simples que devem e que irão moldar de forma mais poderosa primeiro o debate, e em seguida a realidade, do novo século.

\section{O que é e o que não é renda básica}

Renda básica é uma renda paga por uma comunidade politica a todos os seus membros individualmente, independentemente de sua situação financeira ou exigência de trabalho. Esta é a definição que adotarei. Ela não abrange todos os usos reais da expressão inglesa basic income (renda básica), ou de

* Este texto integra o livro Em direção a uma renda de cidadania, a ser lançado em breve, de co-autoria do senador Eduardo Matarazzo Suplicy e Philippe Van Parijs. 
suas traduções mais comuns em outras línguas européias, tais como Bürgergeld, allocation universelle, reddito di cittadinanza, basisinkomen, ou borgerlon. Alguns desses usos reais são mais amplos: eles também abrangem, por exemplo, benefícios cujo valor é afetado pela situação [econômica] da família da pessoa ou que são administrados sob a forma de créditos fiscais. Outros usos são mais restritos: eles também exigem, por exemplo, que o valor da renda básica coincida com aquele que é necessário para satisfazer necessidades básicas ou que ela substitua todas as demais transferências. $\mathrm{O}$ objetivo da definição acima não é o de policiar o seu uso, mas de esclarecer os argumentos. Vejamos cada um de seus componentes resumidamente.

\section{- Uma renda}

Uma renda básica é paga em dinheiro, e não na forma de bens ou serviços. Pode-se conceber um benefício que tenha todas as demais características de uma renda básica mas que seja concedido na forma de bens ou serviços, por exemplo, na forma de uma cesta de alimentos padronizada ou no uso de um lote de terra. Ou poderia ser dado na forma de uma moeda especial com usos restritos, por exemplo vales-alimentação ou créditos habitacionais, ou de maneira mais ampla o direito de consumo somente dentro do período vigente, sem qualquer possibilidade de acumulação desse direito, como na "economia distributiva" de Jacques Duboin (1945). A renda básica, ao contrário, é paga em dinheiro, sem qualquer restrição quanto à natureza ou ao ritmo do consumo ou investimento que ela ajuda a financiar. $\mathrm{Na}$ maioria das variantes, ela complementa, em vez de substituir, transferências na forma de bens ou serviços existentes, tais como ensino gratuito ou seguro de saúde básico.

A renda básica é paga de maneira regular e não como uma doação única. Uma renda básica consiste em poder de compra fornecido a intervalos regulares, tais como uma semana, um mês, um semestre ou um ano, dependendo da proposta. Pode-se também conceber um benefício que tenha todas as outras características de uma renda básica mas que seja pago de uma só vez, por exemplo no início da vida adulta. Isso tem sido proposto ocasionalmente, por exemplo há muito tempo por Thomas Paine (1796) e bem mais recentemente por Bruce Ackerman \& Anne Alstott (1999). Há uma diferença significativa entre uma renda básica regular e uma indenização básica. Entretanto ela não deve ser exagerada. Em primeiro lugar, a indenização básica pode ser investida a fim de gerar uma renda anual ou mensal atuarialmente equivalente até o falecimento do beneficiário, o que resul-

taria em uma renda básica regular. Se fosse aplicado no mercado de seguros, o valor dessa renda anual seria afetado negativamente pela expectativa de 
vida de uma pessoa. As mulheres, por exemplo, receberiam uma renda anual mais baixa do que os homens. Entretanto, os defensores de uma indenização básica (inclusive Paine, Ackerman e Alstott) geralmente a complementam com uma pensão básica uniforme a partir de uma certa idade, a qual elimina a maior parte dessa diferença. Em segundo lugar, enquanto uma indenização básica pode ser usada para outros fins que não o de transformá-la em uma renda anual, a diferença resultante em relação à renda básica seria essencialmente anulada se os beneficiários desta última pudessem tomar empréstimos livremente contra o seu futuro fluxo de renda básica. Mesmo que se proteja sabiamente a renda básica contra embargo por parte de credores, a segurança que ela dá tornará mais fácil para os seus beneficiários tomar empréstimos em qualquer nível e, assim, reduzirá a lacuna entre as séries de opções abertas respectivamente por uma indenização básica única e uma renda básica regular.

\section{- Paga por uma comunidade politica}

Por definição, uma renda básica é paga por um governo de alguma espécie a partir de recursos controlados pelo poder público. Mas ela não precisa ser paga por um Estado-nação. Nem precisa ser paga com recursos provenientes de uma tributação redistributiva.

Aquém e além dos limites do Estado-nação. Na maioria das propostas, supõe-se que a renda básica seja paga, e portanto financiada, em nível de um Estado-nação, como às vezes é indicado pela própria escolha de nomes como "bônus estatal"; "dividendo nacional" ou "salário do cidadão". Entretanto, ela também pode, em princípio, ser paga e financiada no âmbito de uma parte politicamente organizada de um Estado-nação, como uma província ou uma comunidade. De fato, a única unidade política que já introduziu uma renda básica genuína, do modo como é definida, foi o estado do Alasca, nos Estados Unidos (ver Palmer, 1997). Também é concebível que a renda básica possa ser paga por uma unidade política supranacional. Várias propostas têm sido feitas no âmbito da União Européia (ver Genet \& Van Parijs, 1992) e também algumas, mais especulativamente, no âmbito das Nações Unidas (por exemplo, Kooistra, 1994; Frankman, 1998; Barrez, 1999).

Redistribuição. A renda básica pode, mas não precisa necessariamente, ser financiada de um modo específico e vinculado. Se não for, ela é simplesmente financiada juntamente com todos os demais gastos governamentais a partir de um conjunto de receitas de diversas fontes. Dentre aqueles que defendem o financiamento vinculado, a maioria pensa em um imposto específico. Alguns desejam que ela seja financiada por um imposto fundiário ou um imposto sobre recursos naturais (de Thomas Paine (1796) a Raymond 
Crottv (1987), Marc Davidson (1995) ou James Robertson (1999) por exemplo). Outros preferem uma arrecadação específica sobre uma base de cálculo amplamente definida (por exemplo, Pelzer, 1998,1999) ou um imposto sobre valor agregado grandemente expandido (por exemplo, Duchatelet, 1992, 1998). E alguns daqueles que estão pensando em uma renda básica mundial salientam o potencial de novos instrumentos tributários tais como "impostos Tobin" sobre movimentações de capital especulativo (ver Bresson, 1999) ou "impostos bit" sobre transferências de informação (ver Soete, 1996).

Distribuição. A tributação redistributiva, entretanto, não precisa ser a única fonte de financiamento. O sistema de dividendos do Alasca (O'Brien \& Olson, 1990; Palmer, 1997) é financiado com parte do rendimento de um fundo de investimento diversificado, constituído pelo estado com a utilização dos royalties cobrados sobre os vastos campos de petróleo do Alasca. Seguindo a mesma tendência, o projeto de James Meade (1989, 1993, 1994, 1995 ) de uma economia justa e eficiente contém um dividendo social financiado com os rendimentos obtidos sobre os haveres produtivos de propriedade pública. Finalmente, tem havido toda uma seqüência de propostas para financiar a renda básica a partir da criação de moeda, desde o movimento de Crédito Social, de Major Douglas (ver Van Trier, 1997) e o Movimento Francês pela Abundância, de Jacques e Marie-Louise Duboin (1945, 1985), até as recentes obras de Joseph Huber (1998, 1999).

\section{- Para todos os seus membros}

Não-cidadãos? Pode haver concepções mais ou menos abrangentes da filiação a uma comunidade política. Alguns, especialmente entre aqueles que preferem a denominação de "renda do cidadão", entendem a filiação como sendo restrita a cidadãos do país, ou cidadãos em um sentido jurídico. $\mathrm{O}$ direito a uma renda básica é então igual a todo o pacote de direitos e deveres associado à cidadania plena, como na concepção do filósofo francês JeanMarc Ferry (1995). Outros, especialmente entre aqueles que vêem a renda básica como uma política geral contra a exclusão, entendem a filiação em um sentido mais amplo, que tende a incluir todos os residentes legais permanentes no país. O critério operacional pode ser, para não-cidadãos, um prazo mínimo de residência anterior, ou pode simplesmente ser determinado pelas condições que no momento definirem o conceito de residência para fins de tributação.

Crianças? Também pode haver uma concepção mais ou menos abrangente de filiação relacionada à faixa etária. Alguns restringem a renda básica, por definição, a membros adultos da população, porém tendem a propô-la 
paralelamente a um sistema universal de benefício infantil, ou seja, independente da situação financeira dos beneficiários, com um nível de benefício que pode ou não ser diferenciado em função (positiva ou negativa) da classe social ou em função (positiva) da idade da criança. Outros entendem uma renda básica como um direito existente desde o nascimento até a morte e portanto a vêem como um substituto integral do sistema de benefício infantil. $\mathrm{O}$ valor do benefício precisa então ser independente da situação familiar da criança, em particular da sua classe social. Alguns também querem que ela seja igual à dos adultos, e portanto independente de idade, como é atualmente o caso no modesto sistema de dividendos do Alasca e como seria o caso de acordo com algumas propostas mais generosas (por exemplo, Miller, 1983). Porém, a maioria daqueles que propõem uma integração de benefícios infantis ao sistema de renda básica diferenciam o nível desta última de acordo com a idade, sendo o valor máximo concedido somente quando o beneficiário atingir a maioridade ou mais tarde.

Pensionistas? De forma análoga, alguns restringem a renda básica a membros da população que não atingiram a idade para aposentadoria, e portanto a vêem como um complemento natural de uma pensão básica individual, independente da situação financeira dos beneficiários e não-contributiva, fixada em um valor mais elevado, de um tipo que já existe em alguns países europeus, como Suécia e Holanda. Na maioria das propostas, entretanto, a renda básica é concedida após a idade de aposentadoria, quer seja no mesmo valor pago a adultos mais jovens quer em um valor um pouco mais alto. Em todos os casos, esta renda básica para os mais idosos pode ser complementada por uma renda proveniente de sistemas públicos ou privados de pensão contributiva, bem como de poupança privada e do trabalho.

Internos? Mesmo na definição mais abrangente da noção relevante de filiação, qualquer população é passível de conter algumas pessoas que não receberão uma renda básica. Manter criminosos na prisão é muito mais caro para a comunidade do que pagar a eles uma renda básica modesta, mesmo que se leve em consideração qualquer trabalho produtivo que eles possam ser obrigados a realizar. A menos que a detenção se revele como tendo sido injusta, é óbvio que os detentos deveriam perder o benefício de sua renda básica durante o período de sua detenção. Mas eles poderão tê-la de volta logo que forem libertados. O mesmo pode ser aplicado a internos que permanecem por longos períodos em outras instituições, tais como manicômios ou lares de idosos, a ponto de o custo integral de sua permanência ser assumido diretamente pela comunidade, em vez de ser paga pelos próprios internos. 


\section{- Individualmente}

Paga a cada um. A renda básica é paga individualmente a cada membro da comunidade, em vez de a cada unidade familiar tomada como um todo ou a seu chefe, como é o caso na maioria dos sistemas de renda mínima garantida existentes.

Uniforme. Mesmo que um benefício seja pago a cada indivíduo, seu valor ainda poderá ser afetado pela estrutura familiar. Para levar em consideração o fato de que o custo de vida per capita diminui de acordo com o tamanho da família, sistemas existentes de renda mínima garantida concedem uma renda per capita menor aos membros de um casal do que a uma pessoa que viva só. Portanto, um funcionamento justo e eficaz de tais sistemas supõe que a administração deveria ter o poder de verificar as condições sócioeconômicas de seus beneficiários. Uma renda básica, ao contrário, é paga de maneira estritamente individual. Não apenas no sentido de que cada indivíduo membro da comunidade é um beneficiário, mas também de que o valor que a pessoa recebe independe do tipo de família a qual ela pertence. O funcionamento de um sistema de renda básica prescinde, portanto, de qualquer controle sobre as condições sócio-econômicas e preserva todas as vantagens da redução do custo de vida individual por meio do compartilhamento da moradia com outras pessoas. Exatamente por causa de sua natureza estritamente individualista, a renda básica tende a remover o isolamento e incentivar a vida comunitária.

\section{- Sem verificação da situação financeira}

Independente da renda. Em relação a sistemas existentes de renda mínima garantida, o aspecto mais notável da renda básica é sem dúvida o fato de que ela é paga, e no mesmo valor, igualmente a ricos e pobres, sem levar em consideração o seu nível de renda. De acordo com a variante mais simples dos sistemas existentes, especifica-se um nível mínimo de renda para cada tipo de família (adulto solteiro, casal sem filhos, mãe ou pai solteira(o) de uma criança etc.), calcula-se a renda total da família proveniente de outras fontes e a diferença entre esta renda e o mínimo estipulado é paga a cada família na forma de um benefício em dinheiro. Nesse sentido, os sistemas existentes operam ex post, com base em uma avaliação prévia, provisional, da renda do beneficiário. Um sistema de renda básica, ao contrário, opera $e x$ ante, independentemente de qualquer verificação de renda. O benefício é concedido integralmente àqueles cuja renda exceda o mínimo estipulado tanto quanto àqueles cuja renda seja inferior a ele. Também não são levados em consideração quaisquer outros rendimentos ao determinar-se o valor do 
benefício a que uma pessoa tem direito: nem um rendimento informal da pessoa, nem o auxílio que ela possa reivindicar de parentes, nem o valor de seus bens. "Recursos" tributáveis podem precisar ser taxados a uma alíquota média mais alta a fim de financiar a renda básica. Mas o sistema de tributo-ebenefício não mais se apóia em uma dicotomia entre duas noções de "recursos": uma ampla para os pobres, por meio da qual cortam-se benefícios, e uma restrita para os mais privilegiados, por meio da qual cobra-se imposto de renda.

Não torna os ricos mais ricos. Porém, do fato de ricos e pobres receberem a mesma renda básica, não decorre que a introdução de uma renda básica tornaria ricos e pobres mais ricos do que antes. Uma renda básica precisa ser financiada.

Se uma renda básica fosse simplesmente acrescentada a sistemas existentes de impostos e benefícios, é claro que os comparativamente ricos precisariam pagar tanto para sua própria renda básica quanto para a maior parte da renda básica dos comparativamente pobres. Isso obviamente seria válido se o financiamento fosse feito por meio de um imposto de renda progressivo, mas também seria válido no caso de um imposto fixo ou até mesmo um imposto regressivo sobre o consumo. Para que a introdução ex nibilo de uma renda básica proporcione uma vantagem financeira para os pobres, a condição-chave é simplesmente que, com relação a seus números (não necessariamente a sua renda), os relativamente ricos deveriam contribuir mais para o seu financiamento do que os relativamente pobres.

Na maioria das propostas, entretanto, a introdução de uma renda básica é combinada com a extinção parcial de benefícios existentes e a redução de impostos. Se a reforma proposta consistisse apenas em disseminar mais esparsamente entre todos os cidadãos os benefícios não-contributivos atualmente concentrados nos pobres, estes últimos obviamente sairiam perdendo. Mas ninguém está fazendo uma proposta tão absurda. Na maioria das propostas que se apóiam na tributação direta, a renda básica substitui não apenas a parte inferior dos benefícios não-contributivos, mas também as isenções ou alíquotas reduzidas do imposto cobrado sobre a faixa salarial mais baixa de todo contribuinte. O impacto imediato sobre a distribuição de renda pode assim ser mantido dentro de limites razoavelmente estreitos para uma renda básica modesta. Mas quanto mais alto o seu valor, mais alta a alíquota média de imposto de renda e portanto maior a redistribuição dos comparativamente ricos para os comparativamente pobres.

É melhor para os pobres que se dê [também] aos ricos? Assim, dar a todos, ricos e pobres, não visa tornar as coisas melhores para os ricos. Mas, para um 
dado nível de renda mínima, existe alguma razão para acreditar que ela é melhor para os pobres do que uma renda garantida condicionada à verificação da situação financeira dos beneficiários? Sim, por pelo menos três razões inter-relacionadas. Primeiramente, é provável que a taxa de resgate de benefícios seja mais alta em um sistema universal do que se houver uma renda garantida com base em uma verificação da situação financeira do beneficiário. Mais pessoas entre os pobres estarão informadas sobre seus direitos e farão uso dos benefícios a que têm direito. Em segundo lugar, não há nada de humilhante em benefícios concedidos a todos por uma questão de cidadania. Isso não pode ser dito, nem mesmo com os procedimentos menos humilhantes e intrusivos, a respeito de benefícios reservados para os necessitados, os destituídos, aqueles identificados como incapazes de prover a própria subsistência. Do ponto de vista dos pobres, isso pode ser visto como uma vantagem em si, devido ao estigma menor associado a uma renda básica universal. Também importa indiretamente por causa do efeito do estigma sobre a taxa de resgate. Em terceiro lugar, em um sistema de renda básica o pagamento regular e confiável do benefício não é interrompido ao se aceitar um emprego, como seria em um sistema convencional condicionado à situação financeira dos beneficiários. Comparado a sistemas condicionados à verificação da situação financeira dos beneficiários que garantem o mesmo nível de renda mínima, este abre perspectivas reais para pessoas pobres que têm bons motivos para não assumir riscos. Isso significa remover um aspecto da armadilha do desemprego comumente associado a sistemas convencionais de benefícios, um aspecto ao qual os assistentes sociais geralmente são muito mais sensíveis do que os economistas.

Faz o trabalho valer a pena? O outro aspecto da armadilha do desemprego gerada por sistemas de renda mínima garantida condicionados à situação financeira dos beneficiários é aquele salientado com mais freqüência por economistas. Ele consiste na falta de um diferencial de renda positiva significativo entre desemprego e trabalho mal remunerado. No nível mais baixo da distribuição de rendimentos, se cada euro de rendimentos for compensado ou praticamente compensado ou mais que compensado, por uma perda de um euro em benefícios, não será necessário ser particularmente preguiçoso para recusar um emprego que proporcione tais rendimentos, ou procurar ativamente tais empregos. Tendo em vista os custos adicionais, tempo de locomoção ou problemas com os cuidados com filhos, talvez uma pessoa não possa trabalhar sob tais circunstâncias. Além disso, de um modo geral não faria muito sentido para os empregadores criar e oferecer tais empregos, pois é improvável que pessoas que ficariam gratas por serem demitidas constituam uma mão-de-obra escrupulosa e confiável. De qualquer modo, uma legislação sobre salário mínimo pode evitar que empregos de tempo integral 
sejam remunerados com um salário inferior à garantia de renda, caso em que esta última consideração se aplica somente a empregos de meio expediente. A substituição de uma renda garantida condicionada à situação financeira dos beneficiários por uma renda básica universal também é muitas vezes apresentada como uma maneira de combater este segundo aspecto da armadilha do desemprego. Se fosse dada a todos uma renda básica universal, porém fosse tributada em $100 \%$ a parte dos rendimentos de todos que não excedesse a garantia mínima (ver por exemplo Salverda, 1984), a armadilha do desemprego seria igual, neste aspecto, àquela que existiria no caso de uma renda mínima garantida condicionada à situação financeira dos beneficiários (figuras l e 3). Mas se fizermos a suposição de que a alíquota explícita de imposto aplicada à faixa salarial mais baixa deva permanecer sensivelmente abaixo de $100 \%$, então a afirmação seguinte é válida. Uma vez que uma pessoa pode manter o valor integral de sua renda básica, quer esteja trabalhando ou não, quer seja rica ou pobre, ela com certeza estará numa situação melhor quando estiver trabalhando do que quando estiver desempregada (figura 2).

Equivalente a um imposto de renda negativo? Note-se, entretanto, que este segundo aspecto da armadilha do desemprego pode ser removido de maneira tão eficiente, como poderia parecer, por um sistema baseado na situação financeira dos beneficiários que extinguiria o benefício menos abruptamente à medida que aumentassem os rendimentos. Isso é alcançado por meio do chamado imposto de renda negativo, um crédito fiscal uniforme e reembolsável. A noção de um imposto de renda negativo aparece pela primeira vez nas obras do economista francês Augustin Cournot (1838). Ela foi proposta resumidamente por Milton Friedman (1962) como uma maneira de equilibrar o estado de bem-estar social e explorada com mais profundidade por James Tobin $(1965,1966,1967,1968)$ e seus colaboradores como uma maneira de combater a pobreza e ao mesmo tempo preservar os incentivos ao trabalho. Tendo como pano de fundo uma tabela de imposto explícito que não tributa nenhuma renda em $100 \%$ e que pode, mas não precisa ser por definição, linear, um imposto de renda negativo equivale a uma redução do imposto de renda devido por cada família (de uma determinada composição) no mesmo valor fixado, enquanto paga como um benefício em dinheiro a diferença entre este valor e o imposto devido sempre que esta diferença for positiva (figura 3). Suponhamos que o valor do crédito fiscal seja fixado no mesmo nível existente em alguns sistemas de renda básica em exame. Alguém que não tenha renda, e portanto nenhuma obrigação de pagar imposto de renda, receberá um valor igual ao da renda básica. À medida que a renda aumentar, o benefício será reduzido, como no caso de sistemas convencionais condicionados à situação financeira dos beneficiários, 
porém em um ritmo mais lento, na verdade em um ritmo que manterá a renda de transferência após a entrega da declaração exatamente no mesmo nível do sistema de renda básica correspondente (figuras 3 e 4). A variante do Imposto de Renda Negativo (IRN) consiste simplesmente em compensar impostos e benefícios. Em um sistema de renda básica, as receitas necessárias para financiar o crédito fiscal universal do IRN são realmente arrecadadas e restituídas a todos. Sob o sistema do IRN, as transferências são todas num único sentido: transferências positivas (ou impostos negativos) para famílias que estão abaixo do chamado ponto de equilíbrio, transferências negativas (ou impostos positivos) para famílias que estão acima dele (figura 3).

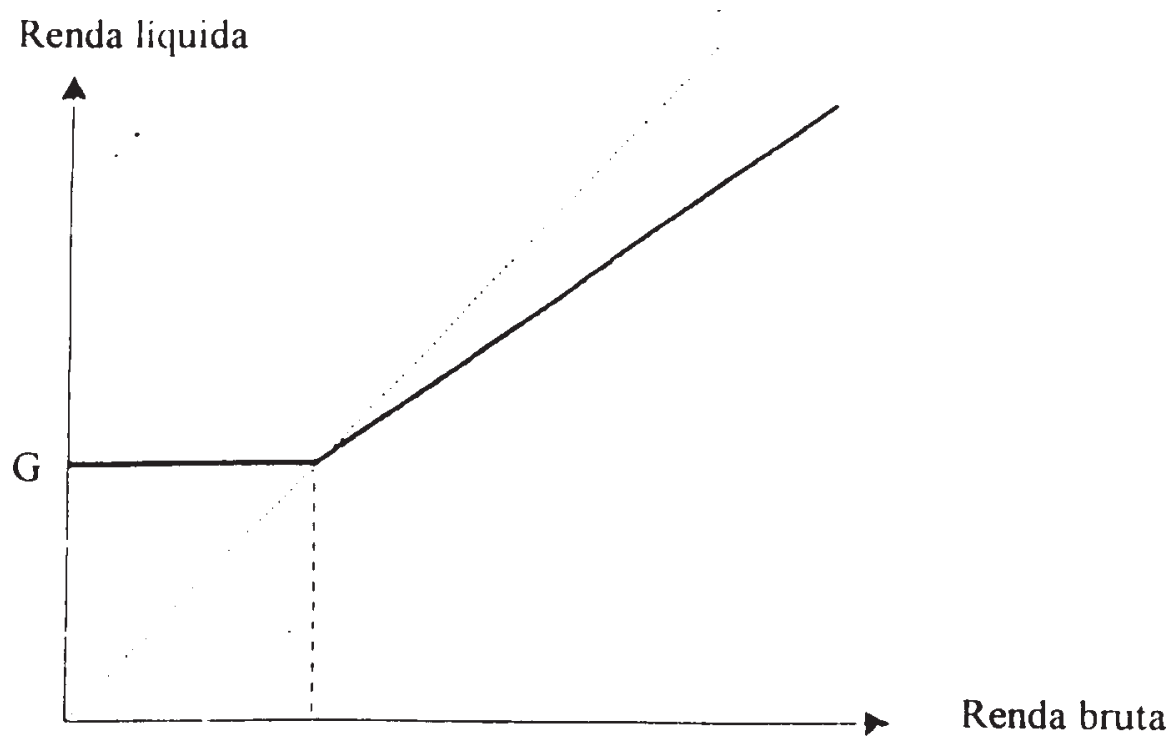

Figura 1. Renda mínima garantida convencional (por exemplo, RMI, Bijstand, Sozialhife etc).

Mais barato que um imposto de renda negativo? O grau de diferença real que há entre uma renda básica e um imposto de renda negativo depende de uma maior especificação de procedimentos administrativos. Ela diminui, por exemplo, se os impostos forem recolhidos na fonte (e não somente depois que as declarações de imposto de renda tiverem sido processadas), ou se os impostos devidos forem calculados em base semanal ou mensal, em vez de anual, ou se todos tiverem direito, em um sistema de IRN, a um adiantamento do crédito fiscal presumível (sujeito a correção posterior), ou se todos tiverem direito, em um sistema de Renda Básica (RB), de receber a RB como uma dedução no imposto em vez de em dinheiro. Mas mesmo na variante mais próxima persiste uma diferença entre um sistema que, por definição, opera ex ante, e um que, por definição, opera, ex post. Qualquer 
diferença remanescente contaria como uma vantagem para a variante da renda básica em relação à primeira dimensão da armadilha do desemprego, ligada à incerteza. Porém, com uma tecnologia rudimentar de pagamento de benefícios (moedas transportadas pelo carteiro!) ou com uma administração de recolhimento de impostos infestada por corrupção ou ineficiência, o argumento a favor da variante do IRN, que acaba com o vai-e-vem do dinheiro dos impostos, pode ser irresistível. Por outro lado, em uma era de transferências tecnológicas e com uma administração tributária razoavelmente bem executada, a maior parte dos custos administrativos associados a um sistema eficiente de renda mínima garantida é representada pelos custos de informação e controle: os gastos necessários para informar todos os beneficiários potenciais sobre quais são seus direitos e verificar se aqueles que os reivindicam preenchem as condições exigidas. Nesses aspectos, um sistema universal com certeza terá um resultado melhor que um sistema condicionado à situação financeira dos beneficiários. À medida que a automatização e a confiabilidade aumentam tanto no lado do pagamento quanto no lado da arrecadação, torna-se cada vez mais provável, no sentido administrativo, que o sistema universal venha a ser o mais barato dos dois na conquista de um certo grau de eficácia para alcançar todos os pobres. É por esse motivo que James Tobin (1997), por exemplo, preferia um "demogrant" universal à variante do imposto de renda negativo.

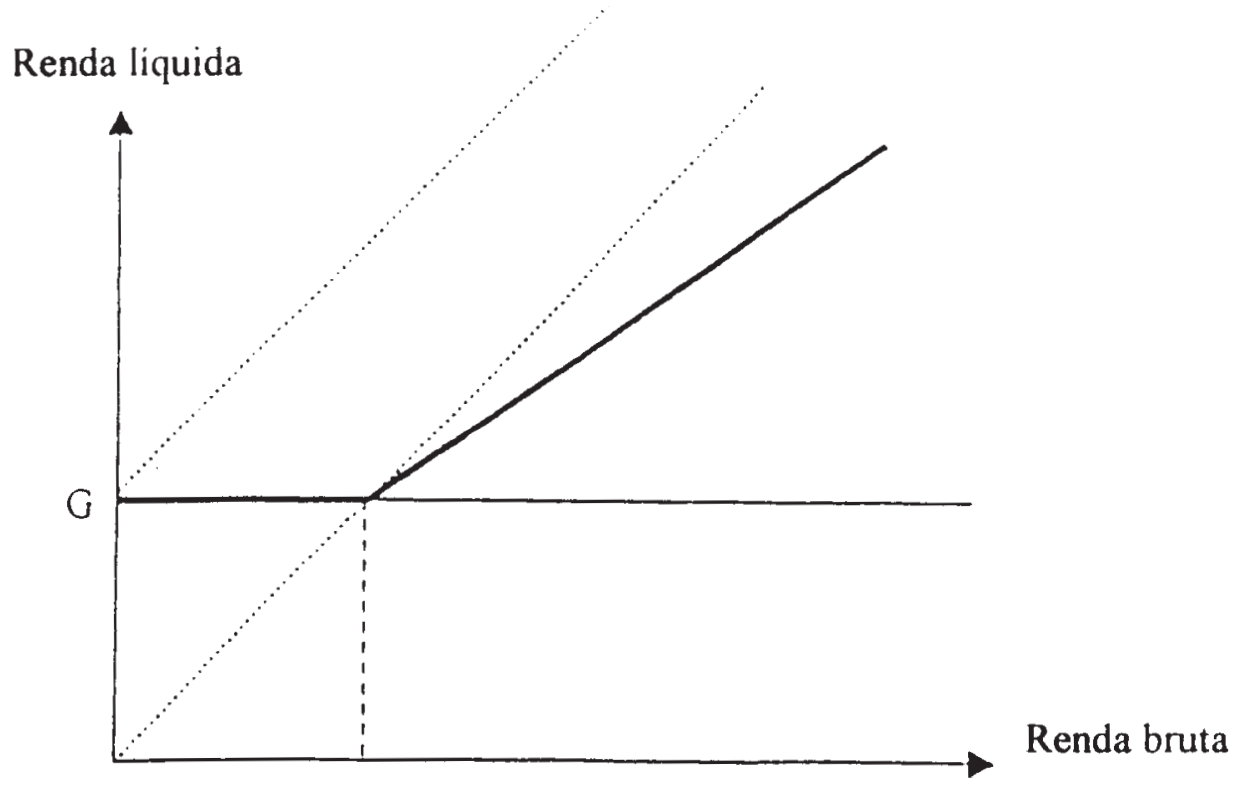

Figura 2. Renda básica com armadilha (por exemplo, Salverva, 1984). 


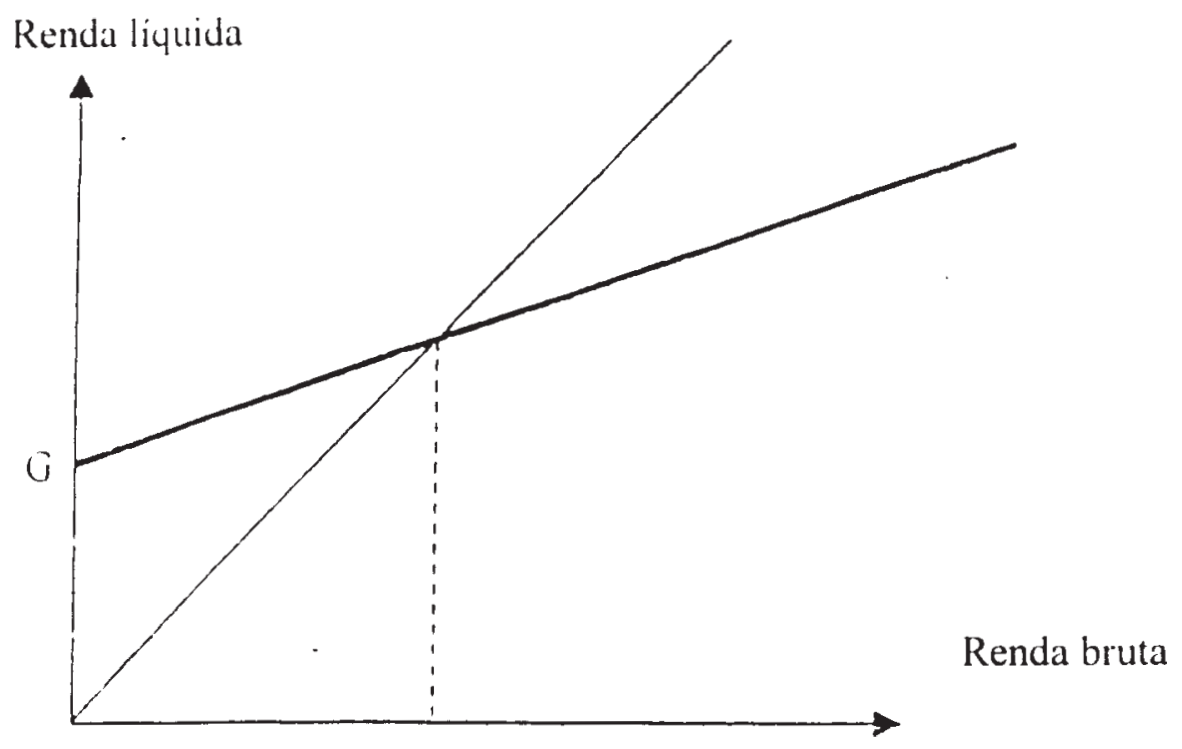

Figura 3. Imposto de renda negativo linear (por exemplo, Friedman, 1962).

\section{- Sem exigência de trabalho}

Independentemente de estar trabalhando. Por definição, o direito a uma renda mínima garantida não se restringe àqueles que trabalharam bastante no passado, ou pagaram contribuições suficientes à seguridade social para terem direito a alguns benefícios do seguro. A partir de Juan Luis Vives (1526), entretanto, suas primeiras variantes estavam muitas vezes vinculadas à obrigação de realizar algum trabalho pesado, quer nas casas de correção antiquadas e mal-afamadas, quer em uma gama mais variada de frentes de trabalho contemporâneas privadas e públicas. Sendo incondicional, uma renda básica contrasta nitidamente com essas formas de renda garantida intimamente vinculadas ao emprego garantido. Ela também diverge de benefícios sociais restritos a famílias em que pelo menos um de seus membros exerce uma atividade remunerada, tais como o crédito fiscal por remuneração recebida nos Estados Unidos, ou mais recentemente o crédito fiscal para famílias de trabalhadores no Reino Unido. Em virtude de eliminar a armadilha do desemprego - ou seja, dar a seus beneficiários um incentivo para trabalhar a renda básica (ou um imposto de renda negativo) pode ser entendida e utilizada como um benefício social ou um aumento de rendimentos. Porém ela não se restringe a essa função. Sua incondicionalidade a distingue de qualquer tipo de subsídio empregatício, por mais amplo que este seja.

Independentemente de disposição para trabalhar. Ela também se distingue de sistemas convencionais de renda mínima garantida, que tendem a 
restringir o direito àqueles dispostos a trabalhar de algum modo. $\mathrm{O}$ teor exato dessa restrição varia muito de país para país, e às vezes de uma jurisdição local para outra dentro do mesmo país. Essa restrição pode prever que a pessoa deva aceitar um trabalho adequado se lhe for oferecido, com uma boa dose de poder de decisão das autoridades administrativas quanto ao significado de "adequado" em termos de localização ou qualificações exigidas; ou que a pessoa deva dar provas de estar ativamente interessada em arranjar um emprego; ou que a pessoa deva aceitar e cumprir um "contrato de inserção", quer vinculado a um emprego remunerado, a um treinamento ou a alguma outra atividade útil. Ao contrário, uma renda básica é paga por uma questão de direito - e não sob falsos pretextos - a chefes de família, estudantes e andarilhos contumazes. Algumas propostas intermediárias, tais como a "renda de participação", de Anthony Atkinson (1993a, 1993b, 1996, 1998), impõem uma condição ampla de contribuição social, que pode ser cumprida por meio de um trabalho assalariado de tempo integral ou parcial ou trabalho autônomo, por meio de estudos, treinamento ou procura ativa por um emprego, cuidados com crianças pequenas ou pessoas idosas debilitadas ou trabalho voluntário regular em uma associação reconhecida. Quanto mais amplamente esta condição for interpretada, menor será a diferença em relação à renda básica.

\section{Por que precisamos de uma renda básica?}

Verificação da situação financeira dos beneficiários necessária somente se não for imposto um teste de trabalho. Juntando-se as duas últimas incondicionalidades discutidas - a ausência da verificação da situação financeira dos beneficiários e a ausência do teste de trabalho - é possível formular sucintamente a essência daquilo que torna a renda básica particularmente relevante nas circunstâncias atuais. À primeira vista, há uma total independência entre estas duas incondicionalidades, entre a ausência de uma verificação da situação financeira dos beneficiários e a ausência de um teste de trabalho. Mas a força da proposta da renda básica depende crucialmente do fato de elas estarem combinadas. A dispensa da verificação da situação financeira dos beneficiários, como vimos, está intimamente ligada à eliminação da armadilha do desemprego (em suas duas dimensões principais), e por conseguinte à criação de um potencial para a oferta e aceitação de empregos de baixos salários que não existe atualmente. Mas alguns desses empregos podem ser desagradáveis, degradantes e sem perspectivas de progresso, o que não deveria ser fomentado. Outros são trabalhos agradáveis, enriquecedores e com perspectivas de avanço, os quais vale a pena aceitar, mesmo que o salário seja baixo, por causa do seu valor intrínseco ou da qualificação que proporcio- 
nam. Quem pode determinar a diferença [entre esses dois tipos de empregos]? Não os legisladores ou burocratas, mas os trabalhadores, pois pode-se acreditar que estes sabem muito mais do que aquilo que é sabido "nos altos escalões" sobre as incontáveis facetas do trabalho que realizam ou pensam em aceitar. Eles têm o conhecimento que os capacitaria a estar fazendo a distinção, mas nem sempre têm o poder para fazê-lo, principalmente se possuem qualificações pouco valorizadas ou mobilidade limitada. Uma renda básica não condicionada à realização de um trabalho dá poder de barganha ao mais fraco de uma maneira que uma renda garantida condicionada ao trabalho não dá. Dito de outro modo, a não-condicionalidade ao trabalho é um instrumento-chave para impedir que a não-condicionalidade à situação financeira leve à proliferação de empregos desagradáveis.

Teste de trabalho desnecessário somente se não for utilizada uma verificação da situação financeira dos beneficiários. Ao mesmo tempo em que os incentivos ao trabalho associados à não-condicionalidade à situação financeira torna a condicionalidade ao trabalho menos tentadora como um modo de atenuar o receio de que benefícios sem uma contrapartida sirvam para nutrir uma subclasse ociosa, na ausência de uma verificação da situação financeira dos beneficiários pode-se esperar que a estrutura tributária e de benefícios seja tal que eles possam aumentar de maneira significativa seus rendimentos disponíveis por meio do trabalho, mesmo que seja um emprego com um baixo salário e de meio expediente, e sem ficar presos nesses empregos uma vez que suas qualificações aumentem ou quando puderem ampliar sua jornada de trabalho. Portanto, a volta ao mercado de trabalho será facilitada e encorajada, e, para aqueles que temem uma dualização da sociedade em trabalhadores e não-trabalhadores, haverá por conseguinte muito menos necessidade de insistir em vincular o direito ao benefício à obrigatoriedade de (estar disponível para) trabalhar. Dito de uma maneira um tanto quanto sucinta: assim como a não-condicionalidade ao trabalho evita que a não-condicionalidade à situação financeira sustente de maneira inaceitável a exploração (o que a segunda faria ao subsidiar empregos indignos e mal remunerados, aceitos sob a ameaça da perda do benefício), de modo semelhante a não-condicionalidade à situação financeira evita que a não-condicionalidade ao trabalho fomente de maneira inaceitável a exclusão (o que a segunda faria ao nos incitar a não mais considerar como problemático um sistema que exclui firmemente o menos produtivo de qualquer participação no trabalho, eliminando de maneira efetiva empregos de baixa produtividade). As duas incondicionalidades-chave da renda básica são logicamente independentes, mas estão intrinsecamente ligadas como componentes de uma forte proposta. 
Ativando ao mesmo tempo em que libera. Esta solidariedade entre as duas incondicionalidades formam a base do argumento central a favor da renda básica como um meio específico de lidar com o desafio conjunto da pobreza e do desemprego. Comparada a sistemas de renda garantida do tipo convencional, o argumento crucial a favor da conveniência da renda básica apóia-se na opinião amplamente compartilhada de que justiça social não é apenas uma questão de direito a uma renda, mas também de acesso a uma atividade (remunerada e não-remunerada). O modo mais eficaz de lidar tanto com a questão da renda quanto com a questão da atividade consiste em manter a transferência de renda (em termos gerais) qualquer que seja a atividade da pessoa, "ativando" assim benefícios, isto é, estendendo-os, além da inatividade forçada, à atividade mal remunerada. Pode-se objetar, com razão, que há outros sistemas - tais como o crédito fiscal por remuneração recebida ou subsídio empregatício - que poderiam alcançar de um modo melhor, ou mais barato, o objetivo de assegurar a viabilidade de empregos de baixa produtividade e assim prover trabalho remunerado àqueles em pior situação. Entretanto, se a preocupação não é manter pessoas pobres ocupadas a qualquer preço, mas sim proporcionar-lhes acesso a uma atividade remunerada que tenha sentido, a própria natureza incondicional da renda básica é uma vantagem crucial: ela possibilita a disseminação de poder de barganha de modo a capacitar (tanto quanto for admissível) os menos favorecidos a distinguir entre empregos atraentes ou promissores e empregos desagradáveis. É, portanto, com base em uma concepção ampla de justiça social, a qual confere ao trabalho a importância que ele merece, e não apesar dela, que o direito a uma renda básica deveria ser tão incondicional quanto é passível de ser estendido a todos de forma sustentável (uma declaração mais precisa e uma argumentação mais completa podem ser encontradas em Van Parijs, 1995).

\section{Uma renda básica é viável?}

Uma pergunta mal formulada. Posta dessa maneira geral, a pergunta não faz sentido. Tenhamos em mente que não faz parte da definição de renda básica que ela deva ser suficiente para satisfazer às necessidades básicas do beneficiário: conforme sua definição, o valor da renda básica poderia ser maior ou menor. Também não faz parte da definição de renda básica que ela deva substituir todos os demais benefícios pagos em dinheiro: um benefício universal não precisa ser um benefício único. Uma resposta à questão da viabilidade que faça sentido só poderá começar a ser dada se se especificar o valor no qual a renda básica deve ser fixada e estipular quais benefícios, se houver, ela deve substituir. De acordo com algumas especificações - por 
exemplo "extinguir todos os benefícios existentes e redistribuir as receitas correspondentes sob a forma de um benefício de valor baixo, igual para todos" -, a resposta é trivialmente sim. Segundo outras especificações - por exemplo "manter todos os benefícios existentes e complementá-los com um benefício igual para todos os cidadãos em um valor suficiente para uma pessoa solteira viver confortavelmente" -, a resposta é obviamente não. Cada uma dessas propostas absurdas e extremas é às vezes igualada, por definição, à renda básica. Mas nenhuma, que eu saiba, foi proposta por alguém. Toda proposta séria encontra-se em algum ponto entre elas. Portanto, a questão da viabilidade de uma proposta de renda básica deve ser analisada caso a caso.

\section{- Mais cara porque não é condicionada ao trabalbo?}

Existem, entretanto, algumas razões gerais pelas quais a renda básica não seria viável em um valor no qual uma renda garantida convencional seria? Uma razão óbvia poderia ser simplesmente o fato de que a renda básica é dada a todos, quer estejam ou não dispostos a trabalhar, enquanto uma renda mínima garantida convencional está subordinada a um teste de disposição para o trabalho. Conseqüentemente, argumenta-se, mais pessoas pobres receberão a renda básica do que uma renda garantida convencional, ou, se o número de beneficiários não for muito maior, eles trabalharão menos do que seria o caso em um sistema de benefício condicionado ao trabalho. Portanto, um sistema de renda básica é com certeza mais caro.

Beneficio aos que procuram emprego versus frentes de trabalho mantidas pelo Estado: um dilema. Um exame mais apurado revela que esta expectativa baseia-se de fato em razões frágeis. Suponhamos primeiro que o teste de trabalho seja concebido como uma obrigação de aceitar trabalho, caso este seja oferecido por algum empregador (privado ou público) preocupado em obter uma melhor relação custo-benefício. Se o trabalhador não desejar aceitar ou conservar o emprego, é improvável que sua produtividade esperada e real sejam tais que o empregador vá querer contratá-lo e mantê-lo no emprego. Mas se o trabalhador estiver formalmente disponível para trabalhar, o fato de ele não ser contratado ou ser demitido (devido a uma produtividade muito baixa, e não a qualquer coisa identificável como má conduta) não poderá desqualificá-lo para o recebimento de uma renda garantida condicionada a um teste de trabalho mais do que para o recebimento de uma renda básica incondicional. A única verdadeira diferença entre a primeira e a segunda é, portanto, simplesmente o fato de que a primeira envolve um desperdício de tempo tanto do empregador quanto do trabalhador. Alternativamente, suponhamos que o teste de trabalho seja concebido como uma obrigação de aceitar um emprego reservado pelo Estado exatamente para 
esse propósito. Arrebanhar o inimpregável e desmotivado não é exatamente uma receita para alcançar alta produtividade, e mesmo sem contar os danos de longo prazo sobre o moral do conscrito e a imagem do setor público, o custo líquido de ajustar este material humano recalcitrante ao molde das frentes de trabalho mantidas pelo Estado poderia ficar pouco abaixo do de uma simples prisão, com o custo de supervisão e correção ofuscando a contribuição dos trabalhadores avessos ao trabalho para o produto nacional. O argumento econômico a favor do teste de trabalho é quase tão forte quanto o argumento econômico a favor das prisões.

Dar aos preguiçosos é mais barato. Portanto, como é plenamente reconhecido por defensores pragmáticos das frentes de trabalho mantidas pelo Estado (como por exemplo Kaus, 1990), se uma condição de disposição para o trabalho tiver que ser imposta, ela deverá ser justificada por meio de razões morais ou políticas, e não de um frágil argumento de custo inspirado pela trôpega presunção de que um benefício atrelado ao trabalho é necessariamente mais barato que o mesmo benefício tomado isoladamente. $\mathrm{O}$ fato de que as frentes de trabalho mantidas pelo Estado são provavelmente mais caras que a assistência social não significa que os "inimpregáveis" devam ser abandonados para degenerar-se em seu isolamento e ócio. Pode e deve haver uma maneira de ajudá-los a sair dessa situação, por exemplo por meio da criação de uma estrutura adequada de incentivos e oportunidades do tipo que uma renda básica universal busca ajudar a criar, quer haja ou não um teste de disposição para o trabalho atrelado a ela. A criação dessa estrutura é dispendiosa, como veremos em seguida, mas acrescentar um teste de trabalho a ela não a tornará mais barata - muito pelo contrário - e a inexistência de tal teste, portanto, não pode ser o que ameaça a viabilidade da renda básica.

\section{- Mais cara por não ser condicionada à situação financeira?}

A equivalência entre sistemas universais e condicionados à situação financeira dos beneficiários. Em vez de se basear no fato de que a renda básica é paga a todos, quer demonstrem ou não qualquer disposição para o trabalho, o argumento de que a renda básica é inviável invoca com mais freqüência ainda o fato de que ela é paga igualmente a ricos e pobres. A discussão anterior sobre a verificação da situação financeira dos beneficiários deve ter tornado óbvio que essa alegação está errada, equivocada por uma noção de custo demasiadamente superficial. Como mostra a comparação procedida nas figuras 1 e 2, em princípio é possível alcançar, por meio de uma renda básica, exatamente a mesma relação entre renda bruta e líquida que se tem com a renda mínima garantida convencional. Se essa relação é a mesma, isso significa que o custo para aqueles contribuintes cujo aporte líquido sustenta 
o sistema é o mesmo em ambos os casos. Se uma é politicamente viável, a outra também deveria sê-lo. Se a relação é a mesma, isso também significa que o imposto marginal sobre rendimentos em qualquer nível de renda é o mesmo em ambos os casos. Portanto, se um dos dois sistemas é economicamente viável, o outro também deveria sê-lo.

Dar aos ricos é mais barato. É óbvio que o custo orçamentário é muito diferente nos dois casos, e se se pudesse raciocinar de maneira sensata sobre transferências do mesmo modo como se raciocina sobre outros gastos públicos, haveria de fato uma forte presunção de que uma renda básica pode ser "inviável”, enquanto uma renda mínima garantida convencional está dentro de nossas possibilidades. Mas transferências não são gastos líquidos. Elas são realocações de poder aquisitivo, o que não significa que não tenham um custo. Na verdade elas têm um custo distributivo para os contribuintes líquidos e um custo econômico através dos desincentivos que criam. Porém, ambos os custos, como vimos, podem ser iguais em qualquer um dos sistemas. Além disso, existem custos administrativos. Mas, como também se salientou anteriormente, supondo-se a existência de uma tecnologia informatizada e eficiente de coleta de impostos e pagamento de transferências, é provável que esses custos sejam mais baixos em um sistema universal ex ante, do que em um sistema ex post sujeito à verificação da situação financeira dos beneficiários, pelo menos para um determinado nível de eficácia em alcançar os pobres. Paradoxalmente, portanto, dar a todos não é mais caro e sim mais barato que dar somente aos pobres.

\section{- Mais caro porque cria incentivos ao trabalbo na base?}

Alíquotas marginais na base e no meio: a grande troca. Para ser justo, entretanto, o fato de a renda básica não estar condicionada à verificação da situação financeira dos beneficiários combina-se naturalmente com a exigência de que a alíquota explícita de imposto deva ser inferior a $100 \%$, o que significa que o tipo de proposta de renda básica que deveríamos considerar não é representado pela figura 2 , mas pela figura 4, ou no mínimo pela 6 . Em relação ao sistema convencional de renda mínima garantida representado pela figura 1, não se pode mais afirmar que não há realmente um custo mais alto. De fato, ele não se apóia exclusivamente na natureza universal do benefício, uma vez que as variantes correspondentes de imposto de renda negativo condicionada à verificação da situação financeira dos beneficiários compartilham exatamente da mesma característica. Em particular, um imposto linear combinado com um crédito fiscal uniforme reembolsável no valor atual da renda mínima garantida (figura 3 ) seria muito caro nesse aspecto. Mas o fato de que o problema deveria ser inteiramente compartilhado com 
sistemas de imposto de renda negativo não o torna um problema menor, que precisa ser encarado de frente. O fato básico é que, quanto mais incentivos materiais se deseja dar (para uma determinada renda mínima) a pessoas que se encontram na base da escala de rendimentos, mais se precisa reduzir os incentivos materiais nos níveis mais altos. Aqui ocorre uma troca acentuada, que pode ser explicitada da seguinte maneira.

Um exemplo. Para fazer com que a reforma tenha um efeito neutro sobre o orçamento e manter a capacidade de pagamento da renda básica a todos, deve-se compensar a redução da alíquota de tributação da faixa mais baixa da renda de todos elevando-se a alíquota de tributação das faixas mais altas. Mas enquanto todos os contribuintes têm rendimentos na faixa mais baixa, nem todos os têm nas faixas mais altas, e quanto mais alta a faixa de renda, menor o número de contribuintes envolvidos. Suponhamos que se comece com um sistema de renda básica do tipo representado na figura 2 , isto é, com uma alíquota de imposto de $100 \%$ na faixa de renda mais baixa, igual à alíquota efetiva de sistemas existentes de renda mínima garantida (figura 1). A redução em $20 \%$ da alíquota média de imposto na faixa de renda mensal compreendida, digamos, entre 0 e 500 euros precisará ser compensada por um aumento da alíquota de imposto nas faixas mais altas. Aumento de quanto? Depende de quantos contribuintes têm renda na faixa acima da qual o aumento do imposto estiver sendo cogitado. Se for na faixa de 500-1000 euros, a maioria dos rendimentos ainda serão afetados pelo aumento e o efeito neutro sobre o orçamento poderá ser alcançado com, digamos, um aumento de $25 \%$ da alíquota de imposto nessa faixa. Mas se for na faixa entre 2000-2500, um número muito menor de contribuintes será afetado, e a alíquota de imposto que equilibra o orçamento precisará ser aumentada em, digamos, mais de $50 \%$. Uma vez que isso tenha sido feito, a conclusão seguinte é inevitável. Se se tiver que financiar uma redução significativa da alíquota de imposto marginal efetiva sobre os rendimentos mais baixos, será preciso aumentá-la de maneira significativa em uma faixa ampla de rendimentos modestos. Concentrar o aumento nas faixas salariais mais altas faria rapidamente com que eles disparassem em direção aos $100 \%$ e faria desaparecer (pelo menos para fins de tributos internos) muito das rendas correspondentes.

É melhor para os pobres que eles sejam mais tributados? Isso não é tão terrível como parece. Os trabalhadores que recebem salários modestos, cuja alíquota de imposto marginal precisaria ser aumentada, estão também entre os principais beneficiários da adoção de um sistema de renda básica, uma vez que a tributação maior de seus salários ficaria abaixo do nível da renda básica que eles passariam a receber. A preocupação, portanto, não precisa ser 
distributiva. Mesmo que se chegue, como em algumas propostas, a um imposto de renda linear, isto é, se os rendimentos mais baixos forem taxados pela mesma alíquota com que os mais altos são taxados atualmente, a reforma ainda assim faria uma redistribuição de cima para baixo, a partir dos contribuintes com renda mais alta (cujo aumento de impostos em todas as faixas de renda excederia sua renda básica). Entretanto, há motivo para uma preocupação legítima com o impacto que tal reforma teria sobre os incentivos. Como ressaltam alguns opositores da renda básica e do imposto de renda negativo (por exemplo, as alíquotas marginais seriam reduzidas em uma faixa na qual há uma proporção de rendimentos marginais da economia possivelmente crescente, mas ainda comparativamente pequena, enquanto seriam aumentadas em uma faixa na qual muito mais trabalhadores seriam afetados), o incentivo ao trabalho, à capacitação, à conscientização e à inovação seria aumentado nas faixas de renda mais baixas (digamos entre $0 \mathrm{e}$ 500 euros por mês), mas seria reduzido a partir desse limite, onde se concentra a maior parte da força de trabalho da sociedade, e particularmente de sua força de trabalho mais produtiva. Portanto seria prudente não aderirmos com demasiada pressa a um sistema no qual a alíquota de imposto marginal efetiva sobre os rendimentos mais baixos não seria mais alta do que sobre os rendimentos mais altos (ver Piketty, 1997).

Sobretaxação dos trabalhadores de baixa renda versus renda básica parcial. Há duas maneiras de acomodar esta orientação em uma proposta de renda básica. Uma consiste em corrigir um sistema linear, ou mesmo progressivo, com uma "sobretaxa" para os beneficiários líquidos da renda básica (figura 6), como sugerido, por exemplo, por James Meade (1989). Uma outra é uma "renda básica parcial", como proposta, por exemplo, pelo Dutch Scientific Council for Government Policy (Conselho Científico Holandês de Política Governamental) (WRR, 1985) e explorada em toda sua extensão desde então, tanto na Holanda (Dekkers \& Noteboom, 1988; de Beer, 1993; van der Veen \& Pels, 1995; Groot, 1999) quanto em outros países europeus (Atkinson, 1989; Parker, 1991; Lahtinen, 1992; Brittan, 1995; Gilain \& Van Parijs, 1995; Clark \& Healy, 1997). Uma renda básica parcial ficaria abaixo do valor da renda garantida atualmente a uma pessoa solteira, mas poderia aproximar-se da metade do valor garantido atualmente a um casal ou até mesmo superar esse valor, e estaria atrelada à manutenção de um sistema residual de renda garantida sujeito à verificação da situação financeira dos beneficiários. Ela implicaria, portanto, a preservação de uma alíquota de imposto efetiva de $100 \%$ sobre uma faixa [de renda] inferior reduzida (figura 7). Em qualquer uma das variantes, o paradoxo anterior torna-se mais agudo: não é apenas melhor para os pobres que os ricos recebam o mesmo que eles. Também é melhor para os pobres que eles sejam mais tributados que os ricos. 


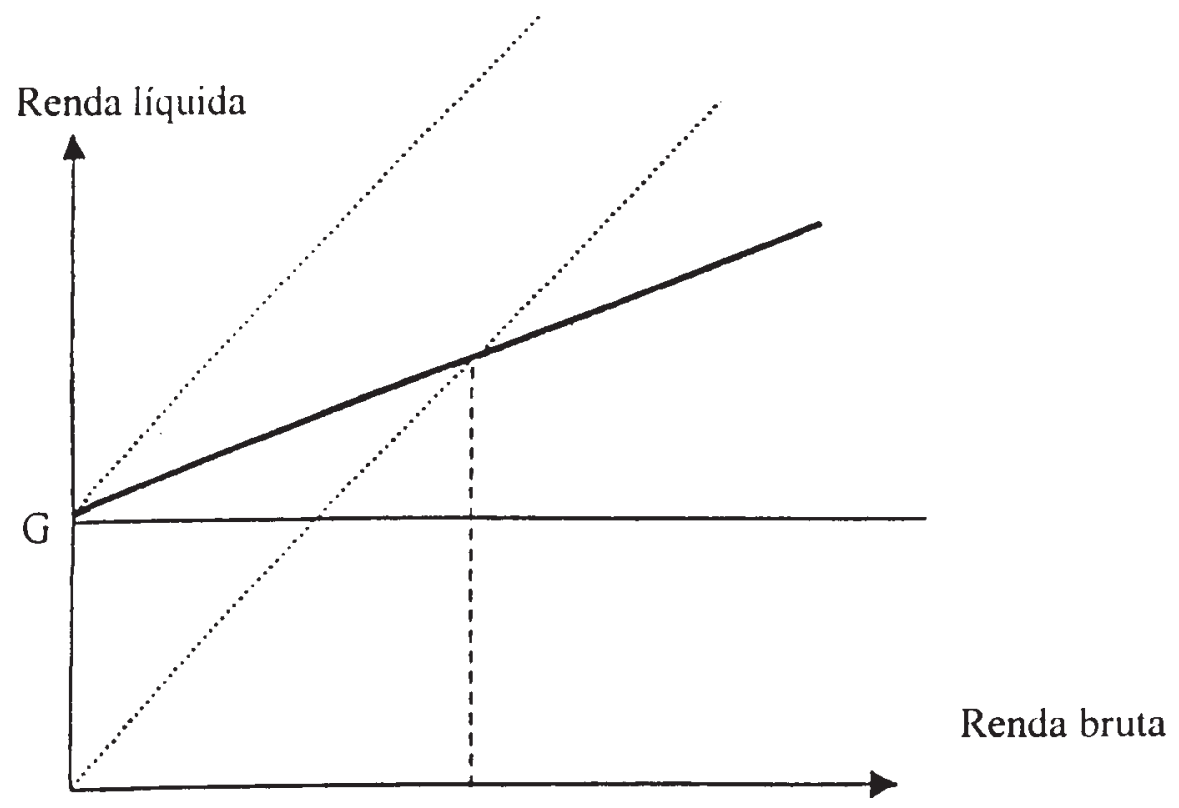

Figura 4. Renda básica combinada com imposto fixo (por exemplo, Atkinson, 1995).

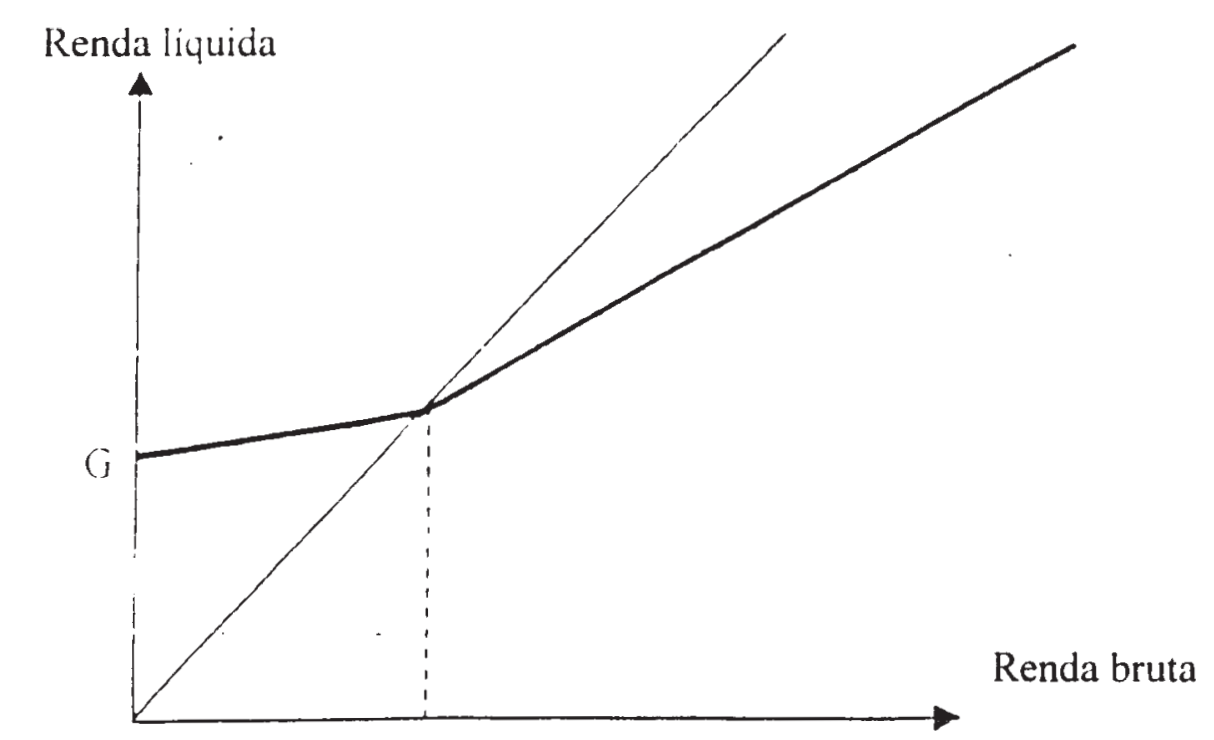

Figura 5. Imposto de renda negativo não-linear (por exemplo, Mitschke, 1962; Godino, 1999). 


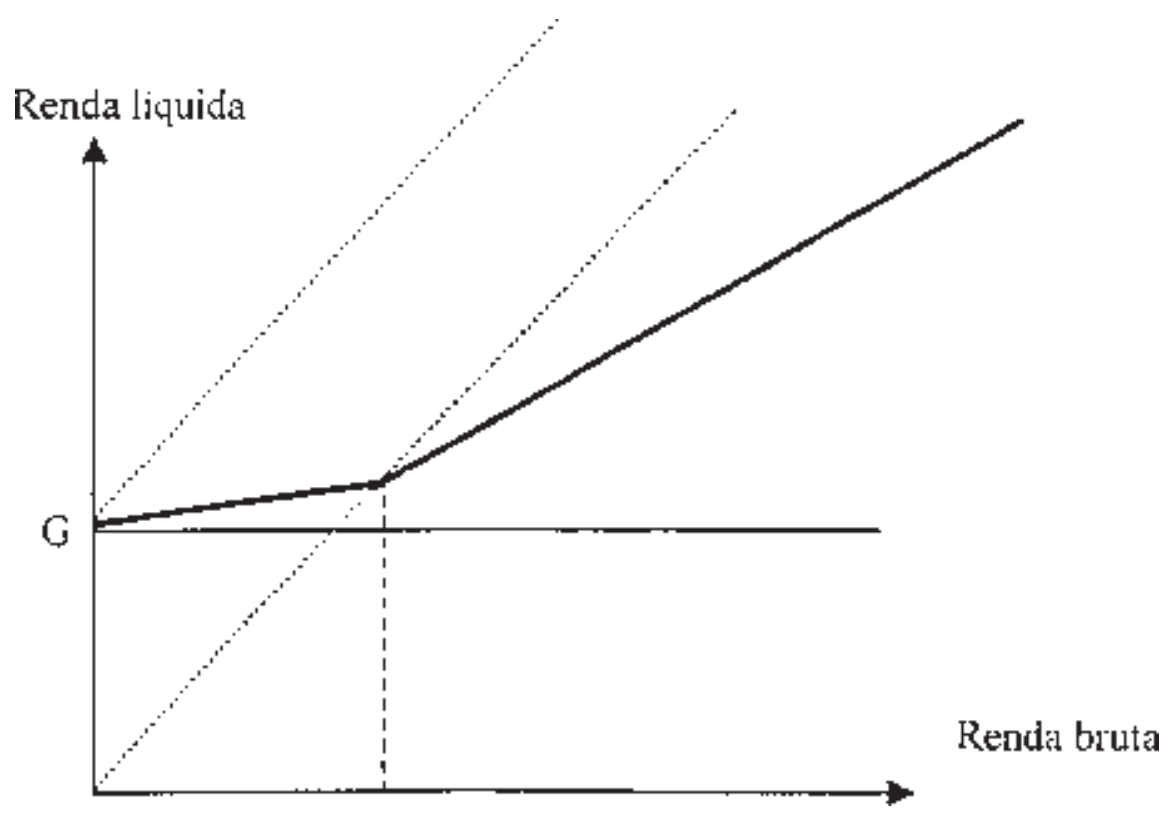

Figura 6. Renda básica com sobretaxa dos trabalhadores de baixa renda (p. ex., Meade, 1989).

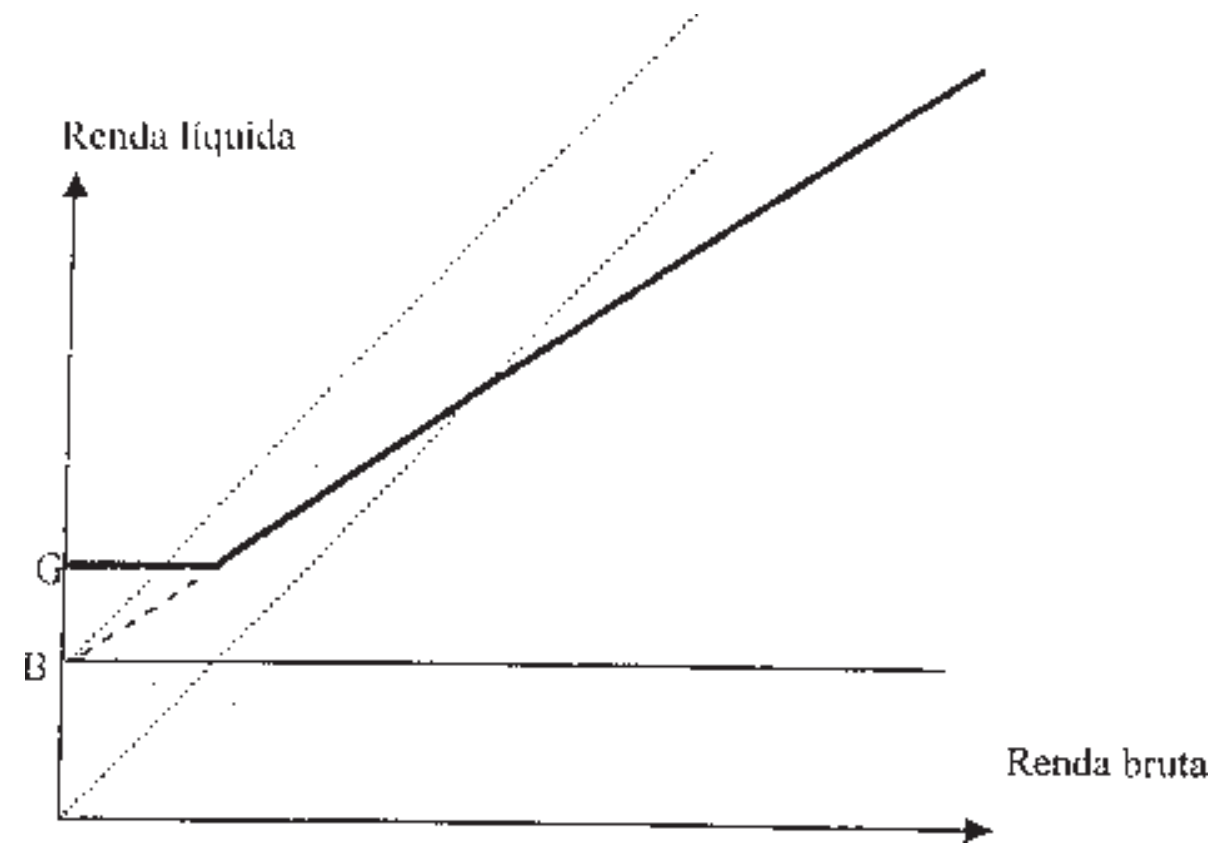

Figura 7. Renda básica parcial (por exemplo, WRR, 1985; Dekkers \& Nooteboom, 1988). 


\section{- Mais caro porque é estritamente individual?}

A beleza da individualização. Desse modo, não se pode negar que a suspensão da verificação da situação financeira dos beneficiários gera um problema real de custos, não em virtude do fato de que a renda básica é dada tanto aos ricos quanto aos pobres, mas porque (parte de) seu objetivo é fornecer aos pobres incentivos materiais mais fortes. Esse não é o único problema real de custos intrínseco a propostas de renda básica. Um outro tem origem direta do fato de que, diferentemente da maioria dos sistemas de renda mínima garantida existentes, a renda básica destina-se a ser estritamente individual. Esses sistemas geralmente fornecem um nível de suporte de renda mais baixo a cada um dos dois membros de um casal do que a uma pessoa solteira, especialmente quando se leva em consideração o subsídio habitacional, às vezes administrado como um benefício à parte. Por que? Obviamente porque é mais barato per capita compartilhar uma residência, bens duráveis (fogão, máquina de lavar, carro, cama?) e alguns serviços (cuidados com crianças) com uma ou mais pessoas do que assumir os custos individualmente. Portanto, o modo mais barato de cobrir uma determinada definição de necessidades fundamentais envolve o rastreamento da estrutura familiar e o ajuste do nível per capita da garantia de renda de acordo com essa estrutura. Como conseqüências naturais desse condicionamento à estrutura familiar, economias de escala são desencorajadas, falsos domicílios recompensados e portanto é preciso verificar as condições de vida das pessoas. Uma das vantagens flagrantes da renda básica é precisamente o fato de que ela acabaria com tudo isso. Pessoas que vivem juntas e assim fazem com que a sociedade economize em moradias e bens de consumo durável teriam direito aos benefícios das economias de escala que elas geram. Portanto, também não haveria bônus para aquelas pessoas que fingem viver separadas quando na verdade vivem juntas e nem necessidade de verificar quem vive onde e com quem.

Um outro dilema: insuficiente ou com base na estrutura familiar? Muito bem, mas em que valor seria fixada a renda básica individual e incondicional? Se for no valor da renda garantida que cada membro de um casal recebe atualmente, o montante com certeza ficaria muito abaixo do necessário para alguém que não tem outra opção a não ser viver só. Se for no valor concedido atualmente a uma pessoa solteira, as implicações de custo, em alguns países em qualquer caso, seriam fenomenais. Mais uma vez não se trata apenas de uma questão de custo orçamentário. Existe um custo distributivo irredutível no sentido de um deslocamento dramático de poder aquisitivo de unidades familiares formadas por um adulto para famílias formadas por dois ou mais adultos. E há também um custo econômico irredutível, devido 
principalmente a um aumento substancial nas alíquotas marginais exigidas a fim de financiar desembolsos com essa renda básica aumentada. Há, portanto, a curto prazo em qualquer caso, um dilema entre conceder uma renda básica totalmente individualizada, mas insuficiente, e conceder uma que seja suficiente, porém ajustada à estrutura familiar (ver Brittan \& Webb, 1991; Brittan, 1995). Note-se, entretanto, que este dilema não deve ser confundido com um dilema entre tornar algumas famílias inaceitavelmente pobres (com uma renda básica individual demasiadamente baixa) e submeter todas as famílias a um controle de suas condições de vida por tempo indeterminado (com uma renda básica suficiente, porém condicionada à estrutura familiar). Mesmo sob restrições de custo de curto prazo, o segundo dilema não se sustenta, pois é possível conceber uma renda básica "parcial” estritamente individual mas insuficiente para todos, combinada com uma assistência social residual muito reduzida, condicionada à verificação da situação financeira e da estrutura familiar dos beneficiários, para o número reduzido daqueles que, apesar do mínimo fornecido pela(s) renda(s) básica(s) da família, não ganham o suficiente para atingir um patamar de renda a partir do qual a assistência condicionada à verificação da situação financeira dos beneficiários é cortada (ver figura 7). A concessão dessa renda básica parcial não é concebida como um substituto integral imediato para a assistência social existente. Desse modo tal renda básica parcial fornece uma maneira atraente de lidar com ambos os problemas reais de custo - os que se originam dos incentivos para trabalhadores de baixa renda e da individualização - que uma renda básica integral provocaria (ver, por exemplo, Gilain \& Van Parijs, 1995 para uma micro-simulação do impacto distributivo de uma tal renda básica parcial no caso da Bélgica).

\section{Que caminho seguir?}

Um olho no futuro e outro no presente. Por motivos explicados em detalhes anteriormente (Van Parijs, 1995), uma concepção coerente e plausível de justiça social exige que almejemos, com algumas qualificações importantes, uma renda básica incondicional no nível mais alto sustentável econômica e ecologicamente, e na escala mais alta politicamente imaginável. Mas embora uma visão de longo prazo justificável seja importante, propostas precisas de ações modestas, imediatamente benéficas e politicamente factíveis não são menos essenciais. O tipo de sistema de renda mínima garantida geral, mas condicionada à verificação da situação financeira e da estrutura familiar dos beneficiários e a um teste de disposição para o trabalho que está sendo aplicado atualmente sob diversas variantes na maioria dos países da União Européia (incluindo mais recentemente Portugal) é um passo fundamental 
na direção certa. Mas quaisquer que sejam as bem-intencionadas condições de "inserção" ou "integração", elas não podem evitar a criação de armadilhas cuja profundidade aumenta quanto maior a generosidade do sistema e cuja ameaça aumenta à medida que a chamada "globalização" intensifica as desigualdades na rentabilidade de mercado. Em países onde sistemas de renda mínima garantida estão sendo aplicados há algum tempo, essas armadilhas e a cultura da dependência que se diz estar associada a elas ameaçam desencadear um retrocesso político e o desmantelamento daquilo que foi alcançado. Mas elas também têm provocado movimentos progressivos na forma de propostas de renda básica e afins. Assim como a luta pelo sufrágio universal, a luta em favor da renda básica não é uma questão de tudo ou nada. Não se trata de um jogo para puristas e fetichistas, mas para amadores e oportunistas. Sem nem mesmo chegar a uma renda básica parcial, as três propostas seguintes são opções plausíveis como o próximo passo mais promissor - mais ou menos plausíveis, dependendo das instituições de cada país, e em especial do seu contexto tributário e de seguridade social.

\section{Um crédito fiscal individual}

A Holanda já dispõe de sistemas universais (ou seja, independentes da situação financeira dos beneficiários) de benefícios infantis, bolsas de estudo e pensões básicas não-contributivas, além de um dos sistemas de renda garantida - condicionada à verificação da situação financeira dos beneficiários mais generosos e abrangentes do mundo. Em janeiro de 2000, o Parlamento holandês aprovou os pontos básicos do plano do governo para uma ampla reforma tributária que inclui a substituição da isenção da faixa inferior de renda por um crédito fiscal estritamente individual em um valor de cerca de 140 euros por mês para todas as famílias com pelo menos um trabalhador (ver Boerlage, 1999). Aumentada gradualmente e tornada individualmente reembolsável (de modo que a (o) companheira(o) desempregada (o) de um (a) trabalhador (a), por exemplo, teria direito a um pagamento em dinheiro equivalente ao crédito, em vez de se creditar em dobro aquele que trabalha), este "imposto de renda negativo" para famílias de trabalhadores forneceria o último elemento que faltava para o pagamento de uma renda mínima universal. Ele poderia então ser incorporado sem traumas a uma renda básica de valor baixo, mas estritamente individual, universal e incondicional. Evidentemente, mesmo em um valor bastante aumentado, esta ainda seria uma renda básica parcial, que precisaria continuar sendo complementada, pelo menos no caso de unidades familiares compostas por um adulto solteiro, por meio de uma assistência residual condicionada à verificação da situação financeira dos beneficiários. 


\section{Um imposto de renda negativo regressivo com base na estrutura familiar}

Apesar de o nome desagradável, esta seria sem dúvida uma mudança importante na direção certa. Sob o nome mais atraente de Bürgergeld, ela tem sido defendida há muitos anos na Alemanha por Joachim Mitschke (1985, 1995), professor de finanças públicas da Universidade de Frankfurt. Fritz Scharpf $(1994,2000)$, diretor do Instituto Max Planck de Colônia, também a tem endossado como sua opção preferida. Mais recentemente, sob o nome mais desgracioso de allocation compensatrice de revenu, uma de suas variantes tem sido defendida na França por Roger Godino (1999), ex-diretor da Escola de Administração INSEAD, e tem sido apoiada de forma cautelosa pelo sociólogo Robert Castel (1999) e pelos economistas François Bourguignon (1999) e Laurent Caussat (2000). A idéia é simplesmente aproveitar a adequação da renda mínima garantida atual à estrutura familiar e, em vez de retirar $100 \%$ do benefício à medida que os rendimentos aumentam, retirá-lo em um percentual um pouco mais baixo, digamos $70 \%$ ou até mesmo $50 \%$, de modo a criar incentivos materiais para o trabalho para qualquer família, por mais baixa que seja sua rentabilidade. Na proposta de Godino para a França, por exemplo, o percentual é calculado de modo que o benefício seria inteiramente eliminado para pessoas solteiras à medida que seus rendimentos atingissem o nível do salário mínimo garantido (ver figura 3), em oposição ao valor muito mais baixo da renda mínima garantida, como é o caso atualmente (figura 1). No caso de uma família maior, o valor inicial é mais alto. Se se aplicar o mesmo percentual reduzido de retirada do benefício, este só será completamente eliminado em um nível de renda que supera o salário mínimo. Uma vantagem política importante desta fórmula é que se pode dizer que ela toma a renda mínima garantida atual como ponto de partida e a fortalece, livrando-se da penalização absurda de qualquer esforço para escapar da armadilha assumindo alguma atividade de baixa remuneração. Uma desvantagem administrativa importante é que ela indica não apenas que um número maior de famílias estará recebendo o benefício (reconhecidamente em um valor médio muito mais baixo), mas também que o valor do benefício a que as famílias têm direito depende de sua situação sócio-econômica, a qual, portanto, o governo deve ser autorizado a fiscalizar.

\section{Uma renda de participação modesta}

Finalmente, é possível tomar como base sistemas existentes de licença maternidade/paternidade, para estudos ou tratamento e integrá-los, juntamente com créditos fiscais para pessoas que estão empregadas, em uma renda básica universal sujeita a uma condição muito geral de contribuição social, 
como proposto, por exemplo, por Anthony Atkinson (1993a, 1993b, 1996, 1998) com o nome de "renda de participação". "A fim de garantir apoio político", Atkinson (1993a) argumenta: "pode ser necessário que os proponentes da renda básica assumam um compromisso. Um compromisso não com base no princípio de que não haja verificação da situação financeira dos beneficiários, nem com base no princípio de independência [isto é, na idéia de que ninguém deveria ser diretamente dependente de qualquer pessoa ou grupo em particular], mas com base no pagamento incondicional". Uma renda de participação seria um subsídio não sujeito à verificação da situação financeira dos beneficiários, paga a toda pessoa que participe ativamente de uma atividade econômica, quer seja remunerada ou não. Pessoas que cuidam de jovens ou idosos, realizam trabalho ou treinamento voluntário reconhecido ou são inválidas em conseqüência de uma doença ou incapacidade também teriam direito a ela. Depois de algum tempo, pode-se perceber bem que pagar fiscais para tentar flagrar os poucos que são realmente avessos ao trabalho custaria mais e criaria mais ressentimentos por toda parte do que simplesmente conceder essa modesta renda mínima a todos, sem fazer perguntas. Mas nesse meio tempo a renda de participação terá, por si mesma, estabelecido politicamente uma renda básica universal. Comparada às abordagens da reforma tributária e da reforma da assistência social, esta terceira abordagem seria particularmente adequada se algum financiamento específico fosse reservado para a renda básica: um imposto sobre o consumo de energia ou um dividendo sobre ativos públicos ou simplesmente algum tributo com base de arrecadação ampla sobre o produto nacional. Mas ela também poderia ser combinada com qualquer uma das duas primeiras abordagens.

\section{As batalhas à frente}

Nos países que já têm algum tipo de renda mínima garantida, há muito trabalho a ser feito em cada uma dessas alternativas, tanto no campo intelectual quanto no campo político. Em outros países, há ainda mais trabalho a ser feito para criar os primeiros ingredientes de um amplo sistema de assistência social, talvez começando com uma pensão universal para os idosos, como na África do Sul, ou talvez combinado com a freqüência escolar obrigatória para as crianças da família (Suplicy \& Buarque, 1996; Sposati, 1997), como no Brasil. Além disso, salientar o argumento a favor de um valor mínimo incondicional para todos não deve nos fazer negligenciar a importância maior de dar educação básica de qualidade a todas as crianças e cuidados básicos de saúde de qualidade a todas as pessoas. Mais importante, porém, para que o modelo aqui defendido se torne algum dia uma realidade comum, é que as batalhas mais difíceis e cruciais podem precisar ser travadas em assuntos aparentemente muito triviais: garantir a eficiência e a responsa- 
bilidade da administração pública, ordenar a migração, desenvolver instituições eleitorais adequadas e estruturar os poderes de organizações supranacionais. Mas estas muitas batalhas podem ganhar direção e força se forem conduzidas por um quadro claro e coerente das principais instituições distributivas de uma sociedade justa e libertadora.

\section{Algumas referências}

Uma extensa bibliografia anotada de muitas publicações em diversas línguas européias pode ser encontrada no web site da Rede Européia de Renda Básica (BIEN):

http:/Iwww.etes. ucl.ac.belbien/bien. html.

O informativo eletrônico da BIEN pode ser obtido gratuitamente enviando-se nome e endereço + "subscribe BIEN" para bien@etes.ucl.ac.be.

O próximo congresso da BIEN será realizado no Wissenschaftszentrum de Berlim, nos dias 6 e 7 de outubro de 2000. Informações disponíveis no site da BIEN ou com o professor Claus Offe, organizador da conferência, no endereço bien@rz.hu-beilin.de

ATKINSON, Anthony B. Analysis of partial basic income schemes, in: A.B. Atkinson. Poperty and social security. Hemel Hempstead, Harvester Wheatsheaf, 1989.

Beveridge. the national mimimum. and its future in a European context, STICERD Working Paper WSP/85, Jan. 1993a.

Participation income. Citizen's Income Bulletinn. 16, p. 7-11, 1993b.

Public economics in action. The basic income flat tax proposal. Oxford,

Oxford University Press, 1995.

The case for a participation income. The Political Quarterly (Oxford), v. 67, n. 1, January-March 1996.

Poverty in Europe. Oxford, Blackwell, 1998.

BARREZ, Dirk. Tien frank per dag voor iedereen. De Morgen, 22 dec. 1999.

BOERLAGE, Saar. Reactie op het belastingplan 2001. Nieuwsbrief Basisinkomen 29, p. 5-8, dec. 1999.

BOURGUIGNON, François \& BUREAU, Dominique. L'architecture des prélèvements en France: etat des lieux et voies de réforme. Paris: La Documentation française, 1999, $142 \mathrm{p}$.

BOVENBERG, A.L. \& van der PLOEG, F. Het basisinkomen is een utopie. EconomischStatistische Berichten 3995, p. 100-104, 1995.

BRESSON, Yoland. Il faut libérer le travail du carcan de l'emploi. Le Monde, 16 mar.1999. 
BRITTAN, Samuel. Capitalism with a human face. Aldershot, Edward Elgar, 1995.

BRITTAN Samuel \& WEBB, Steven. Beyond the Welfare State. An examination of basic incomes in a market economy. Aberdeen, Aberdeen University Press, 1991.

CASTEL, Robert. Minima sociaux, allocation compensatrice de revenu et RMI. In: Castel. Robert, Godino, Roger, Jalmain, Michel \& Piketty, Thomas. Pour une reforme du RMl. Paris, Notes de la Fondation Saint Simon 104, fevrier 1999, p. 39-48.

CAUSSAT, Laurent. Minima sociaux différentiels, allocation universelle, workfare: quels compromis dans la politique française de lutte contre la pauvreté? Communication a la journée d'études “Quelle réforme des minima sociaux?”, Marseille, 14 jan. 2000.

CLARK, Charles M.A. \& HEALY, John. Pathways to a basic income. The Justice Commission, Conference of Religious of Ireland, 1997, 87 p.

COURNOT, Augustin. Recherches sur les principes mathématiques de la théorie des richesses (1838). Paris, Librairie Hachette - new edition. Paris: Marcel Riviere, 1933.

CRONY, Raymond. Ireland in crisis. A study in capitalist colonial development. Dingle (Ireland), Brandon, 1987.

DAVIDSON, Marc. Liberale grondrechten en milieu. Het recht op milieugebruiksruimte als grondslag van een basisinkomen. Milieu 5, p. 246-249, 1995.

de BEER, Paul. Het verdiende inkomen. Houten/ Zaventem, Bohn Stafleu Van Loghum; Amsterdam, Wiardi Beckman Stichting, 1993.

DEKKERS, Jos M. \& Nooteboom, Ban. Het gedeeltelijk basisinkomen, de hervorming van de jaren negentig. The Hague, Stichting Maatschappij en Onderneming, 1998.

DUBOIN, Jacques. La grande relève des hommes par la machine. Paris, Fustier, 1932. L'economie distributive de l'abondance. Paris, OCIA, 1945.

DUBOIN, Marie-Louise. L'économie libérée Paris, Syros, 1985, 59 p.

Guaranteed income as an inheritance. In: A.G. Miller (ed.) Proceedings of the First International Conference on Basic Income. London: BIRG \& Antwerp: BIEN, 1988, p. 134-145.

DUCHATELET, Roland. An economic model for Europe based on consumption financing on the tax side and the basic income principle on the redistribution side. Paper presented at the 5th BIEN Congress, London, Sept. 8-10, 1994, 7 p.

N.V. België. Verslag an de aandeelhouders. Gent, Globe, 1988.

FERRY, Jean-Marc. L'allocation universelle. Pour un revenu de citoyenneté. Paris, Cerf, 1995.

FRANKMAN. Myron. Planet-wide citizen's income: antidote to global apartheid. Montreal, McGill University. Department of Economics, 1998. 
FRIEDMAN, Milton. Capitalism and Freedom, Chicago, University of Chicago Press, 1962.

The case for the negative income tax: a view from the right. J.H. Bunzel (ed.), Issues of American Public Policy. Englewood Cliffs (NJ), Prentice-Hall, 1968, p, 111-120.

GENET, Michel \& VAN PARIJS, Philippe. Eurogrant. BIRG Bulletin, n. 15, p. 4-7, 1992.

GODINO, Roger. Pour la creation d'une allocation compensatrice de revenu. In: Castel, Robert; Godino, Roger; Jalmain, Michel \& Piketty, Thomas. Pour une réforme du RMI. Paris, Notes de Ia Fondation Saint Simon 104, p. 7-20, fév. 1999.

GROOT, Lock F.M. Basic income and unemployment. Amsterdam, Netherlands School for Social and Economic Policy Research, 1999, 240p.

HUBER, Joseph. Vollgeld. Beschäftigung, Grundsicherung und weniger Staatsquote durch eine modernisierte Geldordnung Berlin, Duncker \& Humblot, 1998.

Plain money. A proposal for supplying the Nations with the necessary means in a modern monetary system. Martin-Luther-Universität Halle-Wittenberg, Forschungsberichte des Instituts für Soziologie, 1999, p. 99-103.

JORDAN, Bill; JAMES, Simon; KAY, Helen \& REDLEY, Marcus. Trapped in poverty? Labour-market decisions in low-income households. London/New York, Routledge, 1992.

KOOISTRA, Pieter. Het ideale eigenbelang. Kampen, Kok Agora, 1994.

KRAUSE-JUNK, Gerold. Probleme einer Integration von Einkommensbesteuerung und steuerfinanzierten Sozialleistungen. Anmerkungen zum Gutachten der Expertenkommission. Wirtschaftsdienst n. 7, p. 345-349, 1996.

LAHTINEN, Ilpo. Perustulo, kansalaisen palkka (Basic Income, the Citizen's Wage). Helsinki, Hanki ja Jaeae., 1992

MEADE, James E. Agathotopia: the economics of partnership. Aberdeen, Aberdeen University Press, 1989.

Liberty, equality and efficiency. London, MacMillan, 1993.

Institute, 1994.

Full employment without inflation. London, The Employment Policy

Full employment regained? An agathotopian dream. Cambridge, Cambridge University Press, 1995.

MILLER, Anne. In praise of social dividends. Edimburgh, Heriot-Watt University, Department of Economics, Working Paper 1, Dec. 1983, 54 p.

MITSCHKE, Joachim. Steuer- und Transferordnung aus einem Guss (1985). BadenBaden, Nomos, 1995.

Jenseits der Armenfürsorge. Die Zeit 50, n. 8, p. 30-31, Dec. 1995. 
O'BRIEN, Patrick \& OLSON, Dennis O. The Alaska permanent fund and dividend distribution program. Public Finance Quarterly, v. 18, n. 2, p. 139-156, Apr. 1990.

PAINE, Thomas. Agrarian justice (1796). In: P.F. Foner (ed.), The life and major writings of Thomas Paine. Secaucus (New Jersey), Citadel Press, 1974, p. 605-623.

PALMER, Jim (ed.) Alaska's permanent fund remarkable success at age 20... but what now? Special issue of The Junean Report, Summer 1997.

PARKER, Hermione. Basic income and the labour market. London, Basic Income Research Group, 1991.

PELZER, Helmut. Finanzierung eines allgemeinen Basiseinkommens. Ansätze zu einer kombinierten Sozial- und Stewerreform. Aachen, Shaker Verlag. 1999, 40p.

(ed.). Bürgergeld nach dem Ulmer Modell. Ulm, RV-Verlag microedition. Reihe Wissenschaft, Aug. 1998, 62p.,

PIKETTY, Thomas. La redistribution fiscale face au chômage. Revue française d'économie, v. 12, n. 1, p. 157-201, 1997.

RAVENTOS, Daniel. El derecho a la existencia. Barcelona, Ariel, 1999.

ROBERTSON, James. The new economics of sustainable development. A briefing for policy makers. Luxembourg, Office for Official Publications of the European Communities / London, Kogan, 1999.

SALVERDA, Wim. Basisinkomen en inkomensverdeling. De financiele uitvoerbaarheid van het basisinkomen. Tijdschrift voor Politieke Ekonomie, n. 8, p. 9-41, 1984.

SCHARPF, Fritz W. Negative Einkommensteuer - ein Programm gegen Ausgrenzung. Die Mitbestimmung, v. 40, n. 3, p. 27-32, 1994.

Basic income and social Europe. In: Loek Groot \& Robert J. van der Veen (eds.). Basic income on the agenda. Policies and politics. Amsterdam, Amsterdam University Press, forthcoming, 2000.

SOETE, Luc \& KAMP, Karin. The Bit Tax: agenda for further research. Maastricht, MERIT, Aug. 1996.

SPOSATI, Aldaiza (ed.). Renda minima e crise mundial. Saída ou agravamento? São Paulo, Cortez, 1997.

STANDING, Guy. Global labour flexibility: seeking distributive Justice. Basingstoke, MacMillan, 1999.

SUPLICY, Eduardo (ed.). Programa de garantia de renda minima. Brasilia, Senado Federal, 1992, 275p.

SUPLICY, Eduardo M. \& BUARQUE, Cristovam. A guaranteed minimum income to eradicate poverty and help poor children go to school instead of being forced to work. The Brazilian debate and experience. Paper presented at BIEN'S 6th Congress, Vienna, 12-14 Sept. 1996. 
TOBIN, James. On the economic status of the negro. Daedalus, v. 94, n. 4 , p. 878898, Fall 1965.

41, 1966.

The case for an income guarantee. The Public Interest, n. 4, p. 31-

It can be done. The New Republic, n. 3, p. 14-18, June 1967.

TOBIN, James; PECHMAN, Joseph A. \& MIESZKOWSKI, Peter M. Is a negative income tax practical? The Yale Law Journal, v. 77, n. 1, p. 1-27,1967.

Philippe Van Parijs é professor da Cadeira Hoover de Ética Econômica e Social na Universidade Católica de Louvain.

Documento preparado para o seminário internacional "Políticas e instrumentos para combater a pobreza na União Européia: uma renda mínima garantida" organizado sob a égide da presidência portuguesa da União Européia (Almancil, Portugal, 1-2 fev. 2000)

Escrito como parte do projeto de pesquisa interuniversitário PAl P4/32 "A Nova Questão Social" do Gabinete do Primeiro Ministro do Governo Federal Belga (Serviços Científicos Técnicos e Culturais), o documento foi concebido como núcleo de uma introdução prospectiva à renda básica a ser disponibilizada em hipertexto no site da Rede Européia de Renda Básica (http//www.etes.ucl.ac.be/BIEN/ bien.html).

O texto foi traduzido do inglês por Miguel Araujo de Matos e seu original encontra-se à disposição do leitor no Senado Federal (DF). 